\title{
Feeding habits of Guiana dolphins, Sotalia guianensis, from south-eastern Brazil: new items and a knowledge review
}

\author{
XÊNIA MOREIRA LOPES ${ }^{1}$, EDNILSON DA SILVA ${ }^{1}$, MANUELA BASSOI ${ }^{2}$, ROBERTA AGUIAR DOS SANTOS ${ }^{3}$ \\ AND MARCOS CÉSAR DE OLIVEIRA SANTOS 4 \\ ${ }^{1}$ Projeto Atlantis, Laboratório de Biologia da Conservação de Cetáceos, Departamento de Zoologia, Instituto de Biociências da \\ Universidade Estadual Paulista 'Júlio de Mesquita Filho' (UNESP), Campus Rio Claro, Avenida 24-A, 1515, Bela Vista, Rio Claro, SP, \\ Brazil, ${ }^{2}$ Universidade Federal do Rio de Janeiro, Census of Antarctic Marine Life (CAML), Departamento de Zoologia, Instituto de \\ Biologia, Avenida Pau Brasil, 211, Cidade Universitária, Ilha do Fundão, Rio de Janeiro, RJ, Brazil, ${ }^{3}$ Centro de Pesquisa e Gestão de \\ Recursos Pesqueiros do Litoral Sudeste e Sul (CEPSUL), Instituto Chico Mendes de Conservação da Biodiversidade, Avenida \\ Ministro Victor Konder, 374, Centro, Itajaí, SC, Brazil, ${ }^{4}$ Laboratório de Biologia da Conservação de Mamíferos Aquáticos, \\ Departamento de Oceanografia Biológica, Instituto Oceanográfico da Universidade de São Paulo (USP), Praça do Oceanográfico, \\ 191, Butantã, São Paulo, SP, Brazil
}

\begin{abstract}
This study presents new information on feeding habits of Guiana dolphins, Sotalia guianensis, in south-eastern Brazil, together with new regression equations to evaluate the weight and length of fish from otoliths, showing an overview on the knowledge about this species' diet in this area. Eighteen stomach contents had been analysed and compared to 180 samples collected in another eight feeding studies. The analysed specimens were either incidentally caught in gillnets used in coastal waters by the fleet based in the Cananéia main harbour $\left(25^{\circ} 00^{\prime} S 47^{\circ} 55^{\prime} \mathrm{W}\right)$, south of São Paulo State, or found dead in inner waters of the Cananéia estuary between 2003 and 2009. Based on the index of relative importance analysis, the most important fish species were the banded croaker, Paralonchurus brasiliensis. Doryteuthis plei was the most representative cephalopod species. Stellifer rastrifer was the most important fish species observed in dolphins in inner estuarine waters and P. brasiliensis in recovered dolphins from coastal waters. Loliguncula brevis is the only cephalopod species reported from dolphins found in inner estuarine waters up to date. Doryteuthis plei was the most important cephalopod species observed in coastal dolphins. When considering other feeding studies, the most representative fish family in the diet of S. guianensis was Sciaenidae, which is mainly represented by demersal fishes. The main preys of S. guianensis are abundant in the studied areas, which may indicate an opportunistic feeding habit. The majority of them are not the most important target species by the commercial fishery in south-eastern Brazil.
\end{abstract}

Keywords: Sotalia guianensis, feeding habits, Guiana dolphin, Cetacea, Brazil

Submitted 7 October 2011; accepted 20 March 2012; first published online 22 May 2012

\section{INTRODUCTION}

Assessing the feeding habits of marine mammals is important to define their ecological role, and determine their position within food webs (Pauly et al., 1998). There are various methods of studying feeding habits in marine mammals (see Barros \& Clarke, 2009). The analysis of food remains present in scats, dead animal stomach contents, and in live animal vomits, represents traditional methods which have still been widely used (Barros \& Clarke, 2009). Several other methods have been used, for example stable isotopes (e.g. Newsome et al., 2010), fatty acids (e.g. Iverson et al., 2004; Budge et al., 2006), molecular identification (e.g. Symondson, 2002; Deagle et al., 2005), the use of crittercams (e.g. Iverson et al., 2004) and bioacoustics (e.g. Madsen et al.,

Corresponding author:

X.M. Lopes

Email: xeniamlopes@gmail.com
2005; Benoit-Bird et al., 2008). Identifying and measuring items in vomits, scats and stomach contents have several disadvantages. Cephalopod beaks and fish otoliths remain in the gastrointestinal tracts of marine mammals during different periods of time, therefore the food remains found in one stomach cannot be considered from the same meal. There is also the possibility of contamination with the prey stomach contents. Besides that, prey lacking hard parts may be underrepresented (Fitch \& Brownell, 1968; Clarke, 1986). Even considering these disadvantages, the analysis of food remains provides more information at a considerably lower cost than other methods, and could not be replaced effectively by any other method until now (Barros \& Clarke, 2009). The structures used in prey identification are more resistant to digestion and usually present variation in shape and size among species. Considering stomach content analysis, the most commonly used structures are fish otoliths and cephalopod beaks. Otoliths and beaks enable investigators to estimate the size and weight of the consumed prey (see Clarke, 1962, 1986; Fitch \& Brownell, 1968; Jobling \& Breiby, 1986). Through 
the size and weight of the prey it is possible either to investigate characteristics on the spatial distribution of predators, providing possibilities to monitor alterations in the predator feeding habits, or to investigate the dynamics between prey and predator.

In the western South Atlantic, the knowledge about small cetacean feeding habits comes mainly from studies based on the stomach content analysis. The Guiana dolphin, Sotalia guianensis (Van Benéden, 1864), has been the focus of several studies since the 1960s (e.g. Carvalho, 1963; Borobia \& Barros, 1989; Schmiegelow, 1990; Barros \& Teixeira, 1994). In the past ten years, a considerable amount of studies had contributed to the knowledge about the diet of this species, mostly in south-eastern Brazil (e.g. Zanelatto, 2001; Santos et al., 2002; Gurjão et al., 2003; Oliveira, 2003; Di Beneditto \& Ramos, 2004; Cremer, 2007; Daura-Jorge, 2007; Di Beneditto \& Sciciliano, 2007; Rosas et al., 2010). A total of eight investigations had carefully evaluated 180 stomachs collected in south-eastern Brazil from 1963 to 2005. Information on S. guianensis feeding habits is spatially scattered and should be joined together to better understand its role in trophic interactions. The Brazilian south-eastern coast is inserted in the range of S. guianensis along the coasts of South and Central America (Flores \& Da Silva, 2009). This species is categorized as 'data deficient' by the IUCN Red List of Endangered Species (IUCN, 2010). Throughout its range, human impacts, such as incidental captures in fishing operations, boat traffic, noise pollution, and habitat degradation, have been threatening several populations (see Siciliano, 1994; Santos \& Rosso, 2007; Azevedo et al., 2008; Nery et al., 2008). It is deemed important to evaluate the main prey items of the quoted populations, as well as to compare such items that are economically important along its distribution.

Based on the described scenario, the present study aims to evaluate the stomach contents of 18 individuals collected on the Brazilian south-eastern coast from 2003 to 2009, and to present a comparative review on the knowledge about S. guianensis feeding habits in this area.

\section{MATERIALS AND METHODS}

\section{Field work and study area}

Cananéia $\left(25^{\circ} \mathrm{Oo}^{\prime} \mathrm{S}\right.$ and $\left.47^{\circ} 55^{\prime} \mathrm{W}\right)$ is located on the southern coast of São Paulo State, Brazil (Figure 1). The Cananéia gillnet fleet had been monitored to evaluate cetacean incidental captures from 2004 to 2007 . Boat operations had been surveyed by the crew captain, who had been engaged to fill charts on the following data: GPS position where nets were set, net dimensions, water depth, soaking time, list of captured fish species and number of cetacean incidental capture events. When the cetacean incidental capture had been detected, the individual(s) was/were identified following a log-book and, when possible, was/were brought to land to the research team for natural history studies. Part of the analysed stomachs $(\mathrm{N}=10)$ was recovered from coastal waters by the fishing fleet. Other samples $(\mathrm{N}=8)$ were recovered from dead stranded or floating dolphins, both found in inner waters of the Cananéia estuary. All samples had been recovered from 2003 to 2009 (see Table 1).

\section{Laboratory analyses}

Stomach contents were screened using $200 \mu \mathrm{m}$ mesh sieves. Fishes, cephalopods and crustaceans, whole or fragmented, fish otoliths and cephalopod beaks were selected and stored. Otoliths were dried stored, cephalopod beaks in 1:1 solution of glycerin and $70 \%$ alcohol, and the fragments and whole

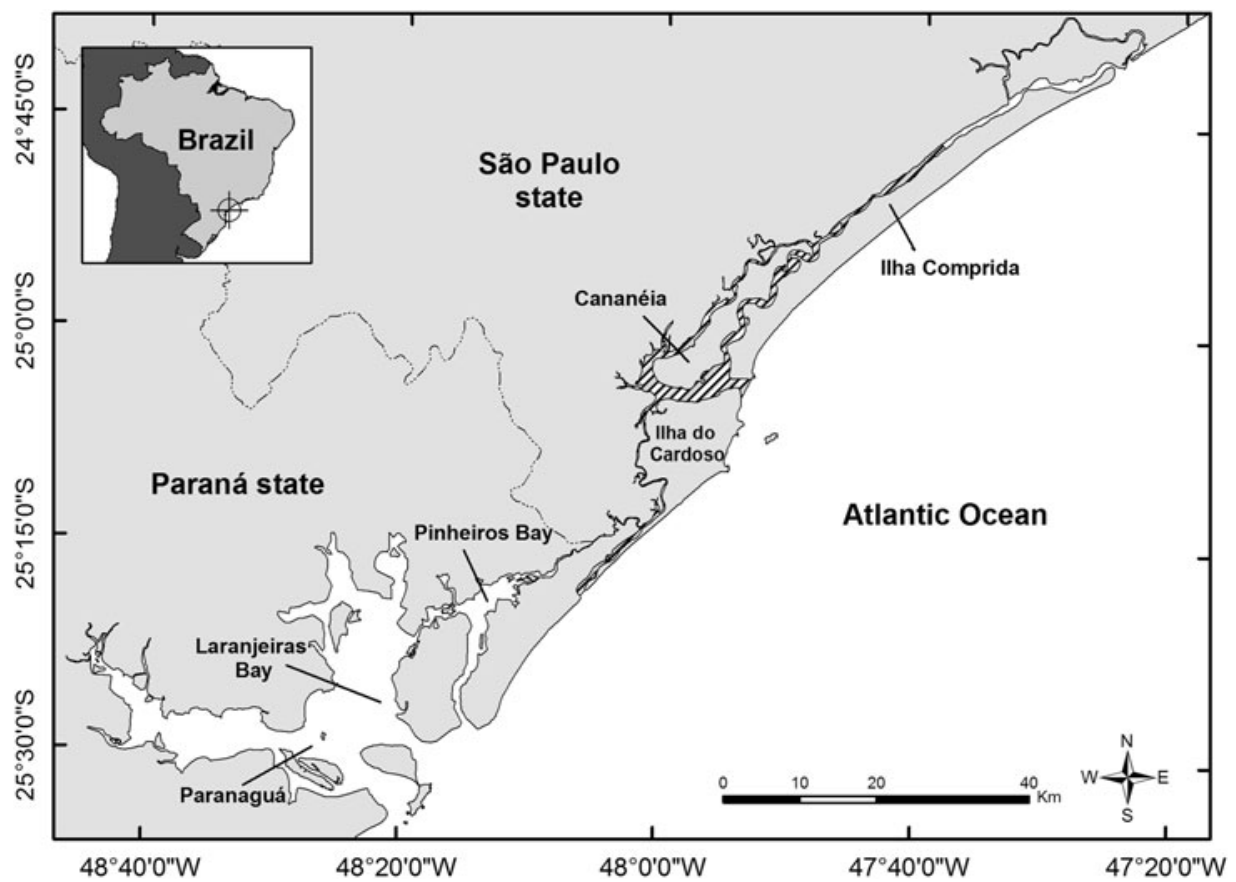

Fig. 1. Sites where Guiana dolphins analysed in the present study were obtained. The individuals considered to be found in inner estuarine waters were the ones obtained in the striped area around Cananéia Island. The individuals considered to be found in coastal waters were the ones incidentally captured in fisheries on the southern coast of São Paulo and northern coast of Paraná. 
Table 1. List of Guiana dolphins, Sotalia guianensis, collected from 2003 to 2009. The field number of each specimen, date and source of event ( $\mathrm{S}$, stranding; B, by-catch; F, found floating in the estuary), water depth (m) of incidental capture, sex and total length $(\mathrm{cm})$ of each are presented.

\begin{tabular}{llllll}
\hline Number & Date & Event & $\begin{array}{l}\text { Water } \\
\text { depth (m) }\end{array}$ & Sex & $\begin{array}{l}\text { Total } \\
\text { length (cm) }\end{array}$ \\
\hline PA-153 & 19-Oct-03 & S & & M & 189 \\
PA-154 & 13-May-04 & S & & M & 183 \\
PA-169 & 04-Aug-05 & S & & F & 101.5 \\
PA-178 & 08-Aug-05 & B & 13 & F & 175 \\
PA-185 & 17-Sep-05 & S & & M & 124 \\
PA-186 & 21-Sep-05 & B & 26 & M & 150 \\
PA-184 & o8-Oct-05 & B & & M & 124 \\
PA-187 & 16-Sep-05 & B & 18 & M & 159 \\
PA-192 & 31-Oct-05 & S & & M & 150 \\
PA-193 & Nov/Dec-05 & B & & F & 191 \\
PA-217 & 18-May-06 & B & 18 & M & 145.5 \\
PA-216 & 03-Jun-06 & B & 13 & M & 163 \\
PA-235 & 01-Nov-06 & S & & M & 172 \\
PA-236 & 19-Dec-06 & B & 20 & F & 146 \\
PA-263 & 31-Mar-07 & B & 15 & M & 146 \\
PA-260 & 08-Apr-07 & B & 20 & M & 148 \\
PA-283 & 21-Aug-09 & B* & & M & 136.5 \\
PA-284 & 16-Oct-09 & F & & M & 132 \\
\hline
\end{tabular}

*, bottom longline in inner waters of the Cananéia estuary; M, male; F, female.

preys were kept in $70 \%$ alcohol, after 24 hours in a solution of $10 \%$ formalin.

The otoliths were used to identify consumed teleost fishes. Prey identification was made through several catalogues (e.g. Bastos, 1990; Abilhôa \& Corrêa, 1992-1993; Corrêa \& Vianna, 1992-1993; Lêmos et al., 1992-1993, 1995a, b). Measurements were taken using a stereomicroscope with metric precision of $0.1 \mathrm{~mm}$. The total length of each otolith was the greatest longitudinal distance toward the groove. The otolith which was used either for identification or for the measurements was the sagitta, also used to estimate the number of fishes consumed by each species. In the genus Stellifer, lapillus otoliths were also found in stomach contents, though these otoliths were neither used to identify species nor to estimate the total number of preys in order to avoid overestimating fishes belonging to this genus. The number of consumed fishes was estimated through the highest number between right or left sagitta otoliths.

Cephalopod beaks were identified using the collection of the 'Centro de Pesquisa e Gestão de Recursos Pesqueiros do Litoral Sudeste e Sul do Instituto Brasileiro do Meio Ambiente e dos Recursos Renováveis (CEPSUL/ICMBIO)'. The measurements of lower rostral length (LRL) and upper rostral length (URL) were taken using a stereomicroscope with ocular micrometer and precision of $0.1 \mathrm{~mm}$ to estimate the mantle length (ML, in $\mathrm{mm}$ ) and weight (WT, in $\mathrm{g}$ ) of squids. When beaks were found, those with highest number (upper or lower) were used to estimate the number of consumed cephalopods and their respective length and weight. Crustaceans were identified by using the identification key of Costa et al. (2003).

\section{Regression equations}

Based on the identified food items found in the present study, samples of fishes with different sizes were obtained in the local market. Fishes were measured, weighted and had their otoliths extracted. Only one otolith sagitta of each individual (right or left) was measured. Standard length (SL) is the distance from the anterior tip to the insertion of caudal fin. The SL was used due to the fact that the majority of species had their caudal fin damaged during the capture, making the total length measurement impossible. When a fish species was not available in adequate numbers, equations gathered in other areas were used (see Bassoi, 2005; Conceição et al., 2005; Bittar, 2007). In the case of cephalopods, equations were compiled from Santos (1999) and CEPSUL/ICMBIO.

\section{Prey importance}

Index of relative importance (IRI) was calculated based on the following formula:

$$
\mathrm{IRI}=(\mathrm{N}+\mathrm{W}) \times \mathrm{F},
$$

where $\mathrm{N}$ is the numerical percentage, $\mathrm{W}$ is the estimated weight percentage and $\mathrm{F}$ is the frequency of occurrence percentage. The numerical, estimated weight and frequency of occurrence percentages and the IRI were analysed separately for fish and cephalopods, since cephalopod beaks remain in cetacean stomachs for a longer period of time than otoliths (Clarke, 1986).

\section{Review on the knowledge about S. guianensis diet in south-eastern Brazil}

Using the 18 samples of this study and nine from a previous one (Santos et al., 2002), a comparison of food items surveyed from dead dolphins recovered in 'inner estuarine' $(\mathrm{N}=12)$ and 'coastal' waters $(\mathrm{N}=15)$ was conducted using the IRI. The sites considered as 'inner estuarine' and 'coastal' are presented in Figure 1. In order to compare the differences between the lengths of fishes and cephalopods found as prey of S. guianensis from both sites, the Mann-Whitney U-test was used. Cephalopods and fishes were analysed separately since they represent preys with different characteristics.

Published studies, theses and dissertations about Guiana dolphin feeding habits in south-eastern Brazilian were revised. Abstracts presented in conferences were not considered. The main food items were evaluated to investigate potential habitat preferences of Guiana dolphin. Also, a comparison between main preys of $S$. guianensis and species known to be the most commercially valuable was conducted. Only studies that showed IRI or F and N were considered.

\section{RESULTS}

From the 18 analysed stomachs, $39 \%$ had only fish remains, $11 \%$ only cephalopod remains, $28 \%$ fish and cephalopod remains, $17 \%$ fish and shrimp remains and about $5 \%$ fish, cephalopod and shrimp remains. A total of 1414 otoliths and 538 cephalopod beaks were found in the stomachs of Sotalia guianensis. From all otoliths, 130 were lapillus from the genus Stellifer and therefore were not used to estimate the total number of prey. Twelve shrimps, 305 cephalopods and 757 fishes were estimated to be ingested by the dolphins. Prey species recorded for S. guianensis are presented in 
Table 2. List of prey items of 18 stomach contents of Guiana dolphins (Sotalia guianensis) found dead in south-eastern Brazil from 2003 to 2009. The number of stomachs in which prey items were found (o), frequency of occurrence percentage (F), number of each prey found (n), numerical percentage $(\mathrm{N})$, estimated weight percentage (W), index of relative importance (IRI) and IRI percentage (IRI\%) are shown.

\begin{tabular}{|c|c|c|c|c|c|c|c|}
\hline Prey species & $\mathbf{O}$ & $\mathbf{F}$ & $\mathbf{N}$ & $\mathbf{N}$ & $\mathbf{W}$ & IRI & IRI\% \\
\hline \multicolumn{8}{|l|}{ Fishes } \\
\hline \multicolumn{8}{|l|}{ Gerreidae } \\
\hline Diapterus lineatus & 3 & 16.67 & 9 & 1.08 & 0.45 & 36.06 & 1.13 \\
\hline \multicolumn{8}{|l|}{ Haemulidae } \\
\hline Orthopristis ruber & 1 & 5.56 & 1 & 0.12 & 0.29 & 2.67 & 0.08 \\
\hline \multicolumn{8}{|l|}{ Trichiuridae } \\
\hline Trichiurus lepturus & 6 & 33.33 & 8 & 0.96 & 7.09 & 286.91 & 8.96 \\
\hline \multicolumn{8}{|l|}{ Carangidae } \\
\hline Trachurus lathami & 1 & 5.56 & 6 & 0.72 & 1.03 & 12.05 & 0.38 \\
\hline Unidentified Carangidae & 1 & & 4 & & & & \\
\hline \multicolumn{8}{|l|}{ Engraulidae } \\
\hline Anchoa tricolor & 1 & 5.56 & 91 & 10.95 & 0.12 & 96.78 & 3.02 \\
\hline Anchoa filifera & 1 & 5.56 & 1 & 0.12 & 0.05 & 1.33 & 0.04 \\
\hline Anchoa sp. & 3 & 16.67 & 4 & 0.48 & 0.16 & $15 \cdot 32$ & 0.48 \\
\hline Cetengraulis edentulus & 1 & 5.56 & 36 & 4.33 & 1.99 & 49.10 & 1.53 \\
\hline Unidentified Engraulidae & 5 & & 105 & & & & \\
\hline \multicolumn{8}{|l|}{ Sciaenidae } \\
\hline Umbrina canosai & 3 & 5.56 & 134 & 0.12 & 0.28 & 2.62 & 0.08 \\
\hline Micropogonias furnieri & 1 & 16.67 & 1 & 0.84 & 0.47 & 29.99 & 0.94 \\
\hline Cynoscion virescens & 3 & 5.56 & 7 & 1.2 & 0.89 & 15.51 & 0.48 \\
\hline Paralonchurus brasiliensis & 1 & 16.67 & 10 & 16.13 & 42.67 & 1135.78 & 35.45 \\
\hline Stellifer sp. & 5 & 27.78 & 73 & 8.78 & 6.78 & 573.93 & 17.91 \\
\hline Isopisthus parvipinis & 2 & 11.11 & 3 & 0.36 & 0.43 & 11.10 & 0.35 \\
\hline Nebris microps & 1 & 5.56 & 2 & 0.24 & 11.17 & 64.15 & 2.00 \\
\hline Ctenosciena gracilicirrhus & 1 & 5.56 & 2 & 0.24 & 0.39 & 4.26 & 0.13 \\
\hline Unidentified Scianidae & 5 & & 15 & & & & \\
\hline \multicolumn{8}{|l|}{ Mugilidae } \\
\hline Mugil sp. & 3 & 16.67 & 4 & 0.48 & 6.86 & 126.99 & 3.96 \\
\hline \multicolumn{8}{|l|}{ Clupeidae } \\
\hline Sardinella brasiliensis & 3 & 16.67 & 134 & 16.13 & 18.88 & 739.33 & 23.08 \\
\hline Achiridae & 1 & & 10 & & & & \\
\hline Bothidae & 1 & & 2 & & & & \\
\hline Ophichtidae & 5 & & 25 & & & & \\
\hline Unidentified fishes & 10 & & 70 & & & & \\
\hline \multicolumn{8}{|l|}{ Cephalopods } \\
\hline \multicolumn{8}{|l|}{ Loliginidae } \\
\hline Doryteuthis plei & 7 & 38.89 & 285 & 31.41 & 69.16 & 3910.8 & 97.40 \\
\hline Loliguncula brevis & 3 & 16.67 & 19 & 5.29 & 0.97 & 104.48 & 2.60 \\
\hline Unidentified Loliginidae & 1 & & 1 & & & & \\
\hline \multicolumn{8}{|l|}{ Crustaceans } \\
\hline \multicolumn{8}{|l|}{ Penaoidea } \\
\hline Litopenaeus schmitti & 1 & & 1 & & & & \\
\hline Farfantepenaeus paulensis & 2 & & 4 & & & & \\
\hline Unidentified Penaoidea & 2 & & 7 & & & & \\
\hline
\end{tabular}

Table 2. Guiana dolphins preyed on at least 19 different fish species, two species of cephalopod and two species of shrimp. The fish minimum length was $1.86 \mathrm{~cm}$ and the maximum length was $95.16 \mathrm{~cm}$. The cephalopod ML range was from $1.99 \mathrm{~cm}$ to $38.45 \mathrm{~cm}$.

The following preys were reported for the first time as food items of S. guianensis in south-eastern Brazil: rough scad, Trachurus lathami, mojarra, Diapterus lineatus and the families Ophictidae and Bothidae. The regression equations to evaluate the weight and length of fishes, and weight and ML of squids are described in Table 3. From 58 equations, $18(31.03 \%)$ are presented for the first time in the study area.

Fishes with higher importance in this study were the banded croaker, Paralonchurus brasiliensis, the orangespot sardine, Sardinella brasiliensis and the rake stardrum,
Stellifer sp. (Table 2). The most commonly reported family was Sciaenidae. It is also important to consider the high $\mathrm{F}$ value found for the Atlantic cutlassfish, Trichiurus lepturus (Trichiuridae) (see Table 2). Doryteuthis plei was the most common cephalopod, due to its higher values of $\mathrm{F}, \mathrm{N}, \mathrm{W}$ and IRI when compared to Lolliguncula brevis. Litopenaeus schmitti and Farfantepenaeus paulensis were the reported shrimp species.

Stellifer rastrifer was the most important fish species, followed by $P$. brasiliensis and S. brasiliensis, when considering samples from inner estuarine waters (Table 4). Only one cephalopod species was recorded in inner estuarine waters: L. brevis. Paralonchurus brasiliensis was the most important fish species found in the stomach of dolphins collected in coastal waters. It was followed by T. lepturus. From the two 
Table 3. Regression equations used to estimate fish standard length (SL) or total length (TL), cephalopod mantle length (ML) and fish and cephalopod weight (W). Sample size, $\mathrm{R}^{2}$ and sources are shown. Otolith length is represented by ' $\mathrm{x}$ ', lower rostral length of cephalopod beaks by 'LRL' and upper rostral length of cephalopods beaks by 'URL'.

\begin{tabular}{|c|c|c|c|c|c|c|c|}
\hline \multirow[t]{2}{*}{ Species } & \multicolumn{3}{|l|}{ Length } & \multicolumn{3}{|l|}{ Weight } & \multirow[t]{2}{*}{ Source } \\
\hline & Sample size & Regression & $\mathbf{R}^{2}$ & Sample size & Regression & $\mathbf{R}^{2}$ & \\
\hline \multicolumn{8}{|l|}{ Fishes } \\
\hline Anchoa filifera & 35 & $\mathrm{SL}=1.9674 \mathrm{x}+1.0401$ & 0.716 & 35 & $\mathrm{~W}=0.2984 \mathrm{x}^{2.4207}$ & 0.689 & $\mathrm{D}$ \\
\hline Anchoa sp. & 82 & $\mathrm{SL}=1.831 \mathrm{x}+1.297$ & 0.671 & 82 & $\mathrm{~W}=0.244 \mathrm{x}^{2.527}$ & 0.694 & $\mathrm{E}$ \\
\hline Anchoa tricolor & 81 & $\mathrm{SL}=1.8311 \mathrm{x}+1.2976$ & 0.672 & 81 & $\mathrm{~W}=0.2443 \mathrm{x}^{2.5275}$ & 0.694 & \\
\hline Cetengraulis edentulus* & - & - & - & 3820 & $\mathrm{~W}=0.0000003 \mathrm{TL}^{3.6708}$ & 0.981 & $\mathrm{~B}$ \\
\hline Ctenosciena gracilicirrhus & 33 & $\mathrm{SL}=1.9064 \mathrm{x}-1.3718$ & 0.96 & 33 & $\mathrm{~W}=0.0496 \mathrm{x}^{3.5123}$ & 0.97 & $\mathrm{C}$ \\
\hline Cynoscion jamaicensis & 12 & $\mathrm{SL}=1.7202 \mathrm{x}-1.1392$ & 0.996 & 12 & $\mathrm{~W}=0.0288 \mathrm{x}^{3.4318}$ & 0.994 & 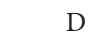 \\
\hline Cynoscion virescens & 23 & $S L=1.4033 x+0.4989$ & 0.99 & 23 & $\mathrm{~W}=0.1029 \mathrm{x}^{2.5646}$ & 0.95 & $\mathrm{D}$ \\
\hline Diapterus lineatus & 37 & $\mathrm{SL}=1.8788 \mathrm{x}+0.2867$ & 0.88 & 37 & $\mathrm{~W}=5.3656 e^{0.13 \mathrm{x}}$ & 0.88 & \\
\hline Eucinostomus argenteus & 15 & $\mathrm{SL}=2.0642 \mathrm{x}+0.8002$ & 0.761 & 15 & $\mathrm{~W}=0.9062 \mathrm{x}^{2.2507}$ & 0.767 & $\mathrm{D}$ \\
\hline Isopisthus parvipinnis & 30 & $S L=1.8563 x-0.7437$ & 0.97 & 30 & $\mathrm{~W}=0.0477 \mathrm{x}^{3.2867}$ & 0.97 & $\mathrm{D}$ \\
\hline Larimus breviceps & 35 & $\mathrm{SL}=1.4164 \mathrm{x}-1.1364$ & 0.991 & 35 & $\mathrm{~W}=0.0519 \mathrm{x}^{3.0227}$ & 0.985 & $\mathrm{D}$ \\
\hline Macrodon ancylodon & 20 & $S L=2.0416 x-4.1130$ & 0.659 & 20 & $\mathrm{~W}=0.0089 \mathrm{x}^{3.8605}$ & 0.733 & $\mathrm{D}$ \\
\hline Micropogonias furnieri & 33 & $\mathrm{SL}=2.0304 \mathrm{x}-2.2003$ & 0.969 & 33 & $\mathrm{~W}=0.0445 \mathrm{x}^{3.3544}$ & 0.968 & $\Gamma$ \\
\hline Mugil sp. & 16 & $S L=0.6505 x^{1.69}$ & 0.61 & 16 & $\mathrm{~W}=0.00412 \mathrm{x}^{5.16}$ & 0.63 & 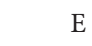 \\
\hline Nebris microps & 22 & $\mathrm{SL}=3.0319 \mathrm{x}-10.226$ & 0.97 & 22 & $\mathrm{~W}=0.0040 \mathrm{x}^{4.5565}$ & 0.98 & $\mathrm{D}$ \\
\hline Orthopristis ruber & 41 & $\mathrm{SL}=1.9896 \mathrm{x}+0.8337$ & 0.717 & 41 & $\mathrm{~W}=0.4409 \mathrm{x}^{2.6658}$ & 0.659 & $\mathrm{E}$ \\
\hline Paralonchurus brasiliensis & 39 & $\mathrm{SL}=2.016 \mathrm{x}-1.8970$ & 0.98 & 39 & $\mathrm{~W}=0.0195 \mathrm{x}^{3.8099}$ & 0.98 & $\mathrm{D}$ \\
\hline Porichthys porisissimus & 54 & $\mathrm{TL}=24.263 \mathrm{x}^{1.0254}$ & 0.994 & 54 & $\mathrm{~W}=0.0809 \mathrm{x}^{3.3225}$ & 0.991 & $\mathrm{C}$ \\
\hline Sardinella brasiliensis & 55 & $\mathrm{SL}=3.5811 \mathrm{x}+3.6082$ & 0.603 & 55 & $\mathrm{~W}=5.3731 e^{0.71 x}$ & 0.6 & $\mathrm{E}$ \\
\hline Stellifer brasiliensis & 30 & $\mathrm{SL}=2.2654 \mathrm{x}-1.9308$ & 0.963 & 30 & $\mathrm{~W}=0.0324 \mathrm{x}^{3.9782}$ & 0.969 & $\mathrm{D}$ \\
\hline Stellifer rastrifer & 30 & $\mathrm{SL}=2.9422 \mathrm{x}-3.796$ & 0.932 & 30 & $\mathrm{~W}=0.0356 \mathrm{x}^{4.2559}$ & 0.944 & $\mathrm{D}$ \\
\hline Stellifer sp. & 127 & $\mathrm{SL}=1.6064 \mathrm{x}^{1.09} 47$ & 0.83 & 127 & $\mathrm{~W}=0.0813 \mathrm{x}^{3.4157}$ & 0.83 & $\mathrm{E}$ \\
\hline Trachurus lathami & 45 & $\mathrm{TL}=20.417 \mathrm{x}^{1.1571}$ & 0.825 & 45 & $\mathrm{~W}=0.0548 \mathrm{x}^{3.5828}$ & 0.815 & C \\
\hline Trichiurus lepturus & 19 & $\mathrm{SL}=17.533 \mathrm{x}-15.885$ & 0.99 & 19 & $\mathrm{~W}=0.1042 \mathrm{x}^{4.6079}$ & 0.99 & $\mathrm{D}$ \\
\hline Umbrina canosai & 30 & $\mathrm{SL}=2.0137 \mathrm{x}^{1}$ & 0.8 & 30 & $\mathrm{~W}=7.4652 \mathrm{e}^{0.33 \mathrm{x}}$ & 0.83 & \\
\hline \multicolumn{8}{|l|}{ Cephalopods } \\
\hline \multirow[t]{2}{*}{ Doryteuthis plei } & - & $\mathrm{ML}=67.431 \mathrm{URL}^{1.2908}$ & 0.961 & - & $\mathrm{W}=8.8096 \mathrm{URL}^{2.8564}$ & 0.980 & \\
\hline & - & $\mathrm{ML}=64.303 \mathrm{LRL}^{1.3143}$ & 0.953 & - & $\mathrm{W}=7.9418 \mathrm{LRL}^{2.908}$ & 0.973 & \\
\hline \multirow[t]{2}{*}{ Loliguncula brevis } & 50 & $\mathrm{ML}=41.3751 \mathrm{URL}+3.3180$ & 0.938 & 53 & $\mathrm{~W}=6.0749 \mathrm{URL}^{2.4677}$ & 0.904 & \\
\hline & 51 & $\mathrm{ML}=42.8967 \mathrm{LRL}+1.8382$ & 0.968 & 53 & $\mathrm{~W}=5.9731 \mathrm{LRL}^{2.5789}$ & 0.918 & 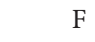 \\
\hline
\end{tabular}

*, Cetengraulis edentulus found in the stomach contents were not digested and therefore were measured and had their weight estimated from the total length. Sources: (A) Santos (1999) (ML in 'mm' and W in 'g'); (B) Conceição et al. (2005) (TL in 'mm' and W in 'g'); (C) Bassoi (2005) (TL in 'mm' and W in ' $\mathrm{g}$ '); (D) Bittar (2007) (SL in 'cm' and W in 'g'); (E) present study (SL in 'cm' and W in ' $\mathrm{g}$ '); (F) Reference collection of CEPSUL/IBAMA (ML in 'mm' and $\mathrm{W}$ in ' $\mathrm{g}$ ').

species of cephalopods found in the coastal dolphin diet, D. plei was the most important item.

Prey specimens were larger in the coastal dolphin diet, with significant differences between fish lengths and cephalopod MLs of prey specimens found in stomach contents of dead dolphins in inner estuarine waters $(1.86 \mathrm{~cm}$ to $28.1 \mathrm{~cm}$; mean \pm standard deviation $(\mathrm{SD})=7.56 \pm 3.73 \mathrm{~cm})$ and in coastal waters $(3.21 \mathrm{~cm}$ to $95.16 \mathrm{~cm}$; mean $\pm \mathrm{SD}=11.87 \pm$ $8.28 \mathrm{~cm}$ ) (fishes: $U_{(\alpha=0.05)}=45065.00 ; P=0.0001 /$ cephalopods: $\left.U_{(\alpha=0.05)}=13691.00 ; P=0.0001\right)$.

The species observed in this study as the most important preys were also reported in the majority of the studies regarding S. guianensis feeding habits (see Table 5). However, among the different sites few differences were observed. For instance, in the studies conducted in the State of Rio de Janeiro north coast $\left(\sim_{22}{ }^{\circ} \mathrm{S}\right)$, the Atlantic cutlassfish was the most important prey (see Di Beneditto \& Ramos, 2004; Di Beneditto \& Siciliano, 2007). On the other hand, in the majority of the studies conducted in the south of São Paulo State and north of Paraná State $\left(\sim 24\right.$ to $\left.25^{\circ} \mathrm{S}\right)$, fishes from the genus Stellifer were the most important prey (see Schimegelow, 1990; Santos et al., 2002; Oliveira, 2003; present study).
The species of cephalopods reported as S. guianensis prey items were mainly squids from the family Loliginidae, except for one octopus, Argonauta nodosa, reported by Zanellato (2001). In the majority of the studies, based on the comparison of the IRI, F and N values, D. plei corresponded to one of the most important cephalopods in the Guiana dolphin diet (see Zanelatto, 2001; Oliveira, 2003; Di Beneditto \& Ramos, 2004; Di Beneditto \& Siciliano, 2007; present study).

On the coast of of Rio de Janeiro State, when considering the most important commercial fish species such as S. brasiliensis, Cetengraulis eduntulus, Katsuwonus pelamis, Micropogonias furnieri, Scomber japonicus and Balistes spp. (see Da Silva \& Vianna, 2009), only M. furnieri was recorded as one of the five most important Guiana dolphin preys (see Di Beneditto \& Ramos, 2004; Di Beneditto \& Siciliano 2007). In south São Paulo and north Paraná, S. brasiliensis, M. furnieri, Cynoscion jamaiscensis, Anchoa spp., Anchoviella spp., Lycengraulis grossidens and Menticirrhus spp. were listed among the most important commercial fishes (see Da Silva \& Vianna, 2009). When considering four studies conducted in the area (Zanelatto, 2001; Santos 
Table 4. Numerical percentage (N), frequency of occurrence percentage (F), estimated weight percentage (W), index of relative importance (IRI) and IRI percentage (IRI\%) of preys observed in the stomachs of Guiana dolphins (Sotalia guianensis) recorded in inner estuarine and coastal waters of southeastern Brazil. Sources: Santos et al. (2002) and present study.

\begin{tabular}{|c|c|c|c|c|c|c|c|c|c|c|}
\hline \multirow[t]{2}{*}{ Prey species } & \multicolumn{5}{|c|}{ Inner estuarine waters } & \multicolumn{5}{|c|}{ Coastal waters } \\
\hline & $\mathbf{N}$ & $\mathbf{F}$ & W & IIR & IIR\% & $\mathbf{N}$ & $\mathbf{F}$ & $\mathbf{W}$ & IIR & IIR\% \\
\hline \multicolumn{11}{|l|}{ Teleostean fishes } \\
\hline \multicolumn{11}{|l|}{ Sciaenidae } \\
\hline Ctenosciena gracilicirrhus & & & & & & 0.78 & 6.67 & 0.50 & 8.51 & 0.17 \\
\hline Cynoscion jamaicensis & 0.17 & 16.67 & 0.43 & 9.92 & 0.25 & & & & & \\
\hline Cynoscion virescens & & & & & & 3.89 & 6.67 & 1.14 & 33.57 & 0.67 \\
\hline Isopisthus parvipinnis & 6.37 & 25 & 3.04 & $235 \cdot 32$ & 5.89 & 1.17 & $13 \cdot 33$ & 0.37 & 20.51 & 0.41 \\
\hline Larimus breviceps & 0.08 & 8.33 & 0.30 & 3.20 & 0.08 & 1.95 & 6.67 & 0.92 & 19.15 & 0.38 \\
\hline Macrodon ancylodon & 0.08 & 8.33 & 1.43 & 12.55 & 0.31 & & & & & \\
\hline Micropogonias furnieri & 1.1 & 41.67 & 3.05 & 172.83 & $4 \cdot 32$ & 1.95 & 13.33 & 3.98 & 79.02 & 1.58 \\
\hline Nebris microps & & & & & & 0.78 & 6.67 & 14.34 & 100.85 & 2.01 \\
\hline Paralonchurus brasiliensis & $4 \cdot 33$ & 25 & 25.50 & 745.76 & 18.66 & 54.47 & $33 \cdot 33$ & 55.26 & 3657.43 & 72.96 \\
\hline Stellifer brasiliensis & 4.42 & 16.67 & 5.54 & 166.07 & 4.16 & & & & & \\
\hline Stellifer rastrifer & 55.56 & 25 & 18.12 & 1842.00 & 46.09 & 10.12 & 13.33 & 0.68 & 143.91 & 2.87 \\
\hline Stellifer sp. & 4.25 & 25 & 3.57 & 195.47 & 4.89 & 8.95 & $13 \cdot 33$ & 5.81 & 196.79 & 3.93 \\
\hline $\begin{array}{c}\text { Umbrina canosai } \\
\text { Haemulidae }\end{array}$ & & & & & & 0.39 & 6.67 & 0.36 & 5.01 & 0.10 \\
\hline Orthopristhis ruber & 0.08 & 8.33 & 0.06 & 1.20 & 0.03 & 0.78 & 13.33 & 0.40 & 15.76 & 0.31 \\
\hline Gerreidae & & & 0.00 & 0.00 & 0.00 & & & & & \\
\hline Eucinostomus argenteus & 0.08 & 8.33 & 0.08 & 1.30 & 0.03 & & & & & \\
\hline $\begin{array}{l}\text { Diapterus rhombeus } \\
\text { Engraulidae }\end{array}$ & 0.25 & 16.67 & 0.36 & 10.22 & 0.26 & 2.33 & 6.67 & 0.29 & 17.45 & 0.35 \\
\hline Anchoa filifera & & & & & & 0.39 & 6.67 & 0.06 & 3.03 & 0.06 \\
\hline Anchoa sp. & 0.25 & 25 & 0.11 & 8.90 & 0.22 & 7 & 20 & 0.74 & 154.78 & 3.09 \\
\hline Anchoa tricolor & 7.73 & 8.33 & 0.19 & 65.98 & 1.65 & & & & & \\
\hline $\begin{array}{l}\text { Cetengraulis edentulus } \\
\text { Mugilidae }\end{array}$ & 3.06 & 8.33 & 3.15 & 51.75 & 1.29 & & & & & \\
\hline $\begin{array}{l}\text { Mugil sp. } \\
\text { Clupeidae }\end{array}$ & 0.42 & 25 & 4.47 & 122.33 & 3.06 & 0.39 & 6.67 & 5.29 & 37.89 & 0.76 \\
\hline $\begin{array}{l}\text { Sardinella brasiliensis } \\
\text { Trichiuridae }\end{array}$ & 11.05 & 8.33 & 28.94 & 333.08 & 8.33 & 1.56 & 13.33 & 0.76 & 30.88 & 0.62 \\
\hline $\begin{array}{l}\text { Trichiurus lepturus } \\
\text { Carangidae }\end{array}$ & 0.08 & 8.33 & 0.04 & 0.97 & 0.02 & 3.11 & 40 & 9.10 & 488.42 & 9.74 \\
\hline Trachurus lathami & 0.51 & 8.33 & 1.63 & 17.80 & 0.45 & & & & & \\
\hline $\begin{array}{l}\text { Cephalopods } \\
\text { Loliginidae }\end{array}$ & & & & & & & & & & \\
\hline Lolliguncula brevis & & & & & & 34.93 & $33 \cdot 33$ & 4.55 & 1315.94 & 14.94 \\
\hline Doryteuthis plei & & & & & & 66.07 & 46.67 & 95.45 & 7491.02 & 85.06 \\
\hline
\end{tabular}

et al., 2002; Oliveira 2003; present study), just a few items such as M. furnieri, Anchoa sp. and S. brasiliensis were listed among one of the five most important Guiana dolphin preys in at least one of the studies.

\section{DISCUSSION}

The present study introduced new food items to the knowledge about the Guiana dolphin diet, even working with a number of stomachs that could be considered small when analysing cetacean feeding habits. It also presented new regression equations to evaluate the weight and standard length of fishes found as Guiana dolphin preys. This is useful information either for predator-prey studies in general, or other studies such as population management and archaeology (Harvey et al., 2000). For the first time, items recovered from stomach contents of dead dolphins found in inner estuarine waters were compared to the ones recovered from coastal dolphins, showing evidences of differences in prey sizes. This study also provided a review of the knowledge about Guiana dolphin diet in south-eastern Brazil, comparing most prey items with the main targets of fisheries.

Considering the 18 analysed stomachs, the fish family with highest species richness in Sotalia guianensis feeding habits was Sciaenidae. This family is commonly found in shallow waters near the coast and some species present great importance in fishery (Menezes \& Figueiredo, 1980). The large representation of Sciaenidae fish in the Guiana dolphin diet has been recorded in previous studies conducted in Brazil (see Table 5). Paralonchurus brasiliensis and Stellifer sp. are demersal fishes associated with sandy or muddy bottoms. Comparing the presented information with a previous study conducted in the same area (Santos et al., 2002) there was apparently no shift in fishes consumed by S. guianensis over the past ten years. Though, due to the samples size, caution must be taken when reaching conclusions about the changes in the dolphin feeding habits over time.

The IRI analysis of individuals found in inner and coastal waters showed differences in their feeding habits, this last also applied to prey on larger items. Maciel (2001) observed that Stellifer rastrifer, the most common prey from dolphins 
Table 5. List of preys consumed by Guiana dolphins (Sotalia guianensis) found dead in south-eastern Brazil. Sources, location where dolphins were found (RJ, Rio de Janeiro; SP, São Paulo; PR, Paraná), and number of stomachs used in each study are presented.

\begin{tabular}{|c|c|c|c|c|c|c|c|c|c|}
\hline Source & A & B & C & $\mathbf{D}$ & $\mathrm{E}$ & $\mathbf{F}$ & G & $\mathbf{H}$ & I \\
\hline State & $\mathrm{RJ} / \mathrm{ES}$ & RJ & RJ & SP & SP & SP & SP/PR & SP/PR & PR \\
\hline Number of stomachs & 4 & 77 & 10 & 9 & 3 & 18 & 7 & 35 & 35 \\
\hline \multicolumn{10}{|l|}{ Teleostean fishes } \\
\hline \multicolumn{10}{|l|}{ Sciaenidae } \\
\hline Ctenosciaena gracilicirrhus & & $\mathrm{x}$ & $\mathrm{x}$ & & & $\mathrm{x}$ & & & $\mathrm{x}$ \\
\hline Cynoscion acoupa & & & & & & & & $\mathrm{x}$ & \\
\hline Cynoscion jamaicencis & $\mathrm{x}$ & $\mathrm{x}$ & $\mathrm{x}$ & $\mathrm{x}$ & & & & & $\mathrm{x}$ \\
\hline Cynoscion leiarchus & & & & $\mathrm{x}$ & & & & $\mathrm{x}$ & \\
\hline Cynoscion striatus & $\mathrm{x}$ & & & & & & & & \\
\hline Cynoscion virescens & & $\mathrm{x}$ & $\mathrm{x}$ & $\mathrm{x}$ & & $\mathrm{x}$ & & & \\
\hline Cynoscion guatucupa & & $\mathrm{x}$ & $\mathrm{x}$ & & & & & & $\mathrm{x}$ \\
\hline Cynoscion sp. & $\mathrm{x}$ & & & & & & & & \\
\hline Isopisthus parvipinnis & & $\mathrm{x}$ & $\mathrm{x}$ & $\mathrm{x}$ & & $\mathrm{x}$ & $\mathrm{x}$ & $\mathrm{x}$ & $\mathrm{x}$ \\
\hline Larimus breviceps & & & & $\mathrm{x}$ & & & $\mathrm{x}$ & $\mathrm{x}$ & \\
\hline Macrodon ancylodon & & $\mathrm{x}$ & $\mathrm{x}$ & $\mathrm{x}$ & & & & & \\
\hline Menticirrhus americanus & & $\mathrm{x}$ & $\mathrm{x}$ & & & & & $\mathrm{x}$ & $\mathrm{x}$ \\
\hline Micropogonias furnieri & & $\mathrm{x}$ & $\mathrm{x}$ & $\mathrm{x}$ & & $\mathrm{x}$ & $\mathrm{x}$ & $\mathrm{x}$ & $\mathrm{x}$ \\
\hline Nebris microps & & $\mathrm{x}$ & & & & $\mathrm{x}$ & & & \\
\hline Paralonchurus brasiliensis & & $\mathrm{x}$ & $\mathrm{x}$ & $\mathrm{x}$ & & $\mathrm{x}$ & & $\mathrm{x}$ & $\mathrm{x}$ \\
\hline Pogonias cromis & & $\mathrm{x}$ & & & & & & $\mathrm{x}$ & \\
\hline Stellifer brasiliensis & & $\mathrm{x}$ & & $\mathrm{x}$ & & & & $\mathrm{x}$ & \\
\hline Stellifer rastrifer & & $\mathrm{x}$ & $\mathrm{x}$ & $\mathrm{x}$ & & & & $\mathrm{x}$ & $\mathrm{x}$ \\
\hline Stellifer sp. & & $\mathrm{x}$ & & & & $\mathrm{x}$ & $\mathrm{x}$ & $\mathrm{x}$ & $\mathrm{x}$ \\
\hline Umbrina sp. & & & & & & & & $\mathrm{x}$ & \\
\hline Umbrina canosai & & $\mathrm{x}$ & & & & $\mathrm{x}$ & & & \\
\hline Unidentified Sciaenidae & $\mathrm{x}$ & & & & $\mathrm{x}$ & $\mathrm{x}$ & $\mathrm{x}$ & & \\
\hline \multicolumn{10}{|l|}{ Haemulidae } \\
\hline Orthopristhis rubber & & $\mathrm{x}$ & $\mathrm{x}$ & $\mathrm{x}$ & & $\mathrm{x}$ & & & $\mathrm{x}$ \\
\hline Haemulon steidachneri & & & & & & & $\mathrm{x}$ & & $\mathrm{x}$ \\
\hline Pomadasys corvinaeformis & & & & $\mathrm{x}$ & & & & & $\mathrm{x}$ \\
\hline Conodon nobilis & & $\mathrm{x}$ & $\mathrm{x}$ & & & & & & \\
\hline Genyatremus luteus & & & & & & & & $\mathrm{x}$ & $\mathrm{x}$ \\
\hline \multicolumn{10}{|l|}{ Gerreidae } \\
\hline Eucinostomus argenteus & & & & $\mathrm{x}$ & & & & $\mathrm{x}$ & \\
\hline Eucinostomus gula & & & & & & & $\mathrm{x}$ & $\mathrm{x}$ & \\
\hline Eucinostomus melanopterus & & & & & & & & $\mathrm{x}$ & \\
\hline Diapterus rhombeus & & & & & & & & $\mathrm{x}$ & $\mathrm{x}$ \\
\hline Diapterus lineatus & & & & & & $\mathrm{x}$ & & & \\
\hline Unidentified Gerreidae & & & & & & & $\mathrm{x}$ & & \\
\hline \multicolumn{10}{|l|}{ Engraulidae } \\
\hline Anchoa filifera & & $\mathrm{x}$ & $\mathrm{x}$ & & & $\mathrm{x}$ & & & \\
\hline Anchoa tricolor & & & & & & $\mathrm{x}$ & & $\mathrm{x}$ & \\
\hline Anchoa sp. & & & & $\mathrm{x}$ & & $\mathrm{x}$ & & & $\mathrm{x}$ \\
\hline Anchoviela lepidentostole & & & & & & & & $\mathrm{x}$ & \\
\hline Cetengraulis edentulus & & & & & & $\mathrm{x}$ & & & $\mathrm{x}$ \\
\hline Lycengraulis grossidens & & & $\mathrm{x}$ & & & & & $\mathrm{x}$ & $\mathrm{x}$ \\
\hline Unidentified Engraulidae & & & & & & $\mathrm{x}$ & $\mathrm{x}$ & & \\
\hline \multicolumn{10}{|l|}{ Mugilidae } \\
\hline Mugil sp. & & $\mathrm{x}$ & & $\mathrm{x}$ & & $\mathrm{x}$ & $\mathrm{x}$ & $\mathrm{x}$ & \\
\hline Mugil curema & & & & & & & $\mathrm{x}$ & & \\
\hline \multicolumn{10}{|l|}{ Paralichthydae } \\
\hline Paralichthys orbignyanus & & & & $\mathrm{x}$ & & & & & \\
\hline Paralichthys sp. & & & & & & & & & $\mathrm{x}$ \\
\hline Citharicthys sp. & & & & & & & & $\mathrm{x}$ & $\mathrm{x}$ \\
\hline \multicolumn{10}{|l|}{ Batracoididae } \\
\hline Porichthys porosissimus & $\mathrm{x}$ & $\mathrm{x}$ & $\mathrm{x}$ & $\mathrm{x}$ & & & $\mathrm{x}$ & $\mathrm{x}$ & $\mathrm{x}$ \\
\hline \multicolumn{10}{|l|}{ Clupeidae } \\
\hline Pellona harroweri & $\mathrm{x}$ & $\mathrm{x}$ & & & & & & $\mathrm{x}$ & $\mathrm{x}$ \\
\hline Harengula clupeola & & & & & & & $\mathrm{x}$ & & \\
\hline Sardinella brasiliensis & & $\mathrm{x}$ & & & & $\mathrm{x}$ & & $\mathrm{x}$ & $\mathrm{x}$ \\
\hline Unidentified Clupeidae & & & & & $\mathrm{x}$ & & $\mathrm{x}$ & & \\
\hline \multicolumn{10}{|l|}{ Trichiuridae } \\
\hline Trichiurus lepturus & $\mathrm{x}$ & $\mathrm{x}$ & $\mathrm{x}$ & $\mathrm{x}$ & & $\mathrm{x}$ & $\mathrm{x}$ & $\mathrm{x}$ & $\mathrm{x}$ \\
\hline
\end{tabular}


Table 5. Continued

\begin{tabular}{|c|c|c|c|c|c|c|c|c|c|}
\hline Source & A & B & C & $\mathbf{D}$ & $\mathbf{E}$ & F & G & & $\begin{array}{l}\text { I } \\
\text { PR }\end{array}$ \\
\hline State & RJ/ES & RJ & RJ & SP & SP & SP & SP/PR & $\mathrm{SP} / \mathrm{PR}$ & PR \\
\hline Number of stomachs & 4 & 77 & 10 & 9 & 3 & 18 & 7 & 35 & 35 \\
\hline \multicolumn{10}{|l|}{ Congridae } \\
\hline Ariosoma opisthophthalma & & $\mathrm{x}$ & $\mathrm{x}$ & & & & & & \\
\hline \multicolumn{10}{|l|}{ Ophichthidae } \\
\hline Myrophis punctatus & & & & & & & & & $\mathrm{x}$ \\
\hline Ophichthus gomesii & & & & & & & & $\mathrm{x}$ & \\
\hline \multicolumn{10}{|l|}{ Unidentified Ophicthidae } \\
\hline \multicolumn{10}{|l|}{ Carangidae } \\
\hline \multicolumn{10}{|l|}{ Oligoplites sp. } \\
\hline Oligoplites saliens & & & & & & & $\mathrm{x}$ & & \\
\hline \multicolumn{10}{|l|}{ Selene setapinnis } \\
\hline \multicolumn{10}{|l|}{ Chloroscombrus chrysurus } \\
\hline Trachurus lathami & & & & & & $\mathrm{x}$ & & & \\
\hline Unidentified Carangidae & & & & & & $\mathrm{x}$ & & & \\
\hline \multicolumn{10}{|l|}{ Gadiidae } \\
\hline Urophycis brasiliensis & & $\mathrm{x}$ & & & & & & & $\mathrm{x}$ \\
\hline Bardiella ronchus & & & & & & & & & $\mathrm{x}$ \\
\hline \multicolumn{10}{|l|}{ Lutjanidae } \\
\hline Lutjanus griseus & & & & & & & & & $\mathrm{x}$ \\
\hline \multicolumn{10}{|l|}{ Synodontidae } \\
\hline \multicolumn{10}{|l|}{ Synodus foetens } \\
\hline \multicolumn{10}{|l|}{ Atherinidae } \\
\hline \multirow{2}{*}{\multicolumn{10}{|c|}{$\begin{array}{l}\text { Atherinella brasiliensis } \\
\text { Serranidae }\end{array}$}} \\
\hline & & & & & & & & & \\
\hline \multicolumn{10}{|l|}{ Dules auriga } \\
\hline \multicolumn{10}{|l|}{ Ariidae } \\
\hline Bagre bagre & & $\mathrm{x}$ & & & & & $\mathrm{x}$ & & \\
\hline \multicolumn{10}{|l|}{ Achiridae } \\
\hline Achirus sp. & & & & & & & & $\mathrm{x}$ & \\
\hline Unidentified Achiridae & & & & & & $\mathrm{x}$ & & & \\
\hline Bothidae & & & & & & $\mathrm{x}$ & & & \\
\hline Ophichtidae & & & & & & $\mathrm{x}$ & & & \\
\hline Unidentified fishes & $\mathrm{x}$ & $\mathrm{x}$ & & $\mathrm{x}$ & & $\mathrm{x}$ & $\mathrm{x}$ & $\mathrm{x}$ & \\
\hline \multicolumn{10}{|l|}{ Cephalopods } \\
\hline \multicolumn{10}{|l|}{ Loliginidae } \\
\hline Lolliguncula brevis & $\mathrm{x}$ & $\mathrm{x}$ & & $\mathrm{x}$ & & $\mathrm{x}$ & & $\mathrm{x}$ & $\mathrm{x}$ \\
\hline Doryteuthis plei & & $\mathrm{x}$ & $\mathrm{x}$ & & & $\mathrm{x}$ & $\mathrm{x}$ & $\mathrm{x}$ & $\mathrm{x}$ \\
\hline Doryteuthis sanpaulensis & & $\mathrm{x}$ & $\mathrm{x}$ & & & & & $\mathrm{x}$ & $\mathrm{x}$ \\
\hline Doryteuthis sp. & $\mathrm{x}$ & & & & & & & & \\
\hline Unidentified Loliginidae & & & & & & $\mathrm{x}$ & $\mathrm{x}$ & & \\
\hline \multicolumn{10}{|l|}{ Argonautidae } \\
\hline Argonauta nodosa & & & & & & & & & $\mathrm{x}$ \\
\hline Unidentified cephalopods & & & & & & & & $\mathrm{x}$ & \\
\hline Crustaceans & & & & & & & & & \\
\hline Penaeoidea & & & & & & & & & \\
\hline Farfantepenaeus paulensis & & & & $\mathrm{x}$ & & $\mathrm{x}$ & & & \\
\hline Farfantepenaeus brasiliensis & & & & & & & $\mathrm{x}$ & $\mathrm{x}$ & \\
\hline Litopenaeus schmitti & & & & $\mathrm{x}$ & & $\mathrm{x}$ & & & \\
\hline Unidentified shrimps & & & & $\mathrm{x}$ & & & & & \\
\hline
\end{tabular}

Sources: (A) Borobia \& Barros (1989); (B) Di Beneditto \& Ramos (2004); (C) Di Beneditto \& Siciliano (2007); (D) Santos et al. (2002); (E) Carvalho (1963); (F) present study; (G) Schmiegelow (1990); (H) Oliveira (2003); (I) Zanelatto (2001).

found in inner estuarine waters, was the most abundant species collected by bottom trawling in the Cananéia estuary. The Atlantic cutlassfish (Trichiurus lepturus) did not represent an important species in the feeding habits of Guiana dolphins found in inner estuarine waters. However, it was the second prey in importance for the individuals found in coastal waters. Trichiurus lepturus is distributed from coastal waters to $300 \mathrm{~m}$ of depth (Magro, 2005). The observation of smaller preys in estuarine dolphins could be related to the common presence of juvenile fishes in the estuary, which is an important breeding area for several fish species (Besnard, 1950; Schaeffer-Novelli et al., 1990).

The only cephalopod species reported from the individuals found in inner estuarine waters was Loligunculla brevis; meanwhile this species and Doryteuthis plei were reported for coastal dolphins. Doryteuthis plei occurs at depths of up to $370 \mathrm{~m}$ and is not common in estuaries (Roper et al., 1984). This squid also corresponds to one of the most common cephalopod species on the Brazilian coast (see Perez et al. 2005; Haimovici et al., 2007; Rodrigues \& Gasalla, 2008). 
Lolliguncula brevis corresponds to a coastal species found at depths up to $20 \mathrm{~m}$. It tolerates salinities as low as $8.5 \mathrm{ppm}$ for brief periods, and is particularly abundant in shallow bays and estuaries (Roper et al., 1984). The significant difference in the estimated consumed cephalopods size could also be related to the differences between the two species consumed. Lolliguncula brevis is a small squid with $12 \mathrm{~cm}$ maximum ML for females and $8 \mathrm{~cm}$ for males, and $D$. plei is larger, with $35 \mathrm{~cm}$ maximum ML for males and $22 \mathrm{~cm}$ for females (Roper et al., 1984). Doryteuthis plei was observed only for individuals found in coastal waters and, therefore, this surveyed Guiana dolphin group presented larger MLs in their stomachs. The difference between the consumption of cephalopods by coastal and inner estuarine waters dolphins may represent a difference in feeding site. The absence of D. plei beaks in stomachs of inner estuarine Guiana dolphins may represent that this group had not fed in coastal waters for some time before they were found, since cephalopod beaks remain for long periods in stomach contents. Even with such compelling evidences, caution must be taken when reaching conclusions about differences between feeding habits of individuals found in inner estuarine and coastal waters, because the location where individuals were found stranded does not necessarily represent the place they fed. Thus, more studies using stomach content analysis and also other techniques should be deployed for evaluating differences in feeding habits regarding Guiana dolphins in inner and coastal waters.

All the most important prey species in S. guianensis diet are abundant in the studied areas, which represents evidence of opportunistic feeding habit. The difference among the species composition reported in diverse studied areas reflects the different biota composition in those sites. When considering the studies presented in Table 4, the most representative fish family was Sciaenidae, which is predominantly demersal (Menezes \& Figueiredo, 1980). Most of the species found as important preys of $S$. guianensis are associated with the sea bottom. Even species such as T. lepturus and D. plei, which also present pelagic habits, may be associated with the bottom based on their vertical migration. Large adults of Atlantic cutlassfish usually feed near the surface in daytime and migrate to the bottom at night; meanwhile juveniles form schools near the bottom during the day and feed near the surface at night (Figueiredo \& Menezes, 2000). Doryteuthis plei concentrates near the bottom during the day, but disperses into the water column at night (Roper et al., 1984). Considering the applied methodology, it is not possible to describe in which day period, and, therefore, where S. guianensis consumed these two preys. Thus, coastal and estuarine substrates seem to be important to Guiana dolphins' feeding activities. Disturbances that affect the sea bottom (e.g. estuarine mouth dredging and bottom trawling) may decrease prey availability and possibly affect the feeding activity, one of the vital processes for this species' survival.

It is also important to consider that the overlap between Guiana dolphin preys and fisheries' main targets appears not to occur when fishes are taken into consideration. Sciaenidae, the most representative family in S. guianensis diet, is abundant and is commercially important (Souza, 2004). Notwithstanding, the species which were found to be more frequently ingested by Guiana dolphins (e.g. Stellifer sp. and $P$. brasiliensis) did not represent the most important target species from the commercial fishery (see Menezes \&
Figueiredo, 1980; Mendonça, 1998; Mendonça et al., 2003, 2004; Da Silva \& Vianna, 2009), even though they are frequent in bottom trawl fisheries by-catch. Trichiurus lepturus is commercially important around the world, but in Brazil it still has low commercial values (Bittar, 2007).

In Rio de Janeiro State, the overlap between the Guiana dolphin diet and fishery targets had been observed when considering Micropogonias furnieri (see Di Beneditto \& Siciliano, 2007). Nevertheless, $M$. furnieri presented a low value of the IRI when compared to the four most important species in that study (T. lepturus, Cynoscion guatocupa, Isopisthus parvipinnis and Porichthys porosissimus). These four species corresponded to $86.3 \%$ of the total biomass reported, $74.3 \%$ of all the preys consumed and each species was reported in at least $30 \%$ of the analysed stomachs, suggesting that $M$. furnieri has a lower importance in Guiana dolphins' feeding habits. In south São Paulo and north Paraná, the situation was similar to the one observed in Rio de Janeiro. Even though listed among the five most important species, Sardinella brasiliensis (present study) and M. furnieri (Santos et al., 2002) appear not to be of greatest importance in Guiana dolphins' feeding habits. In the present study, S. brasiliensis was reported as an important prey due to one individual that consumed 130 of 134 reported orangespot sardines. Micropogonias furnieri presented a higher value of F (44.4\%) in the study of Santos et al. (2002), but presented an extremely low value of $\mathrm{N}(1.1 \%)$.

When considering the cephalopods alone, the overlap with fisheries had been observed, $D$. plei has a high commercial value (Perez et al., 2005). Though, when considering the general importance in fishery, this species does not represent one of the ten most import products in the south-eastern Brazilian fishery (see Da Silva \& Vianna, 2009).

The feeding habit studies enhance our knowledge about marine mammals in the ecosystems, hence contributing to information for future conservation issues. Currently, the S. guianensis studies in Brazil have been concentrated mostly in the south-eastern region. Therefore, studies in other areas along the Guiana dolphin distribution are necessary to better understand either its trophic interactions, or its interaction with commercial fishery. The use of different available techniques (e.g. stable isotopes and fatty acids) to evaluate long-term diet and energy consumption would also provide complementary information to better understand the Guiana dolphin diet along its distribution, and perhaps between different stocks.

\section{ACKOWLEDGEMENTS}

Logistic support was provided by the Instituto Oceanográfico da Universidade de São Paulo. Fishes used in the regressions were supplied by 'Peixaria do Jura', 'Cabeça Pescados', 'Miami Comércio, Exportação de Pescados LTDA' and 'M. PREY Comércio de Pescados'. Jocemar Tomasino Mendonça (Instituto de Pesca de Cananéia) helped in shrimp identification. Helinho and Ricardo Prey kindly allowed the monitoring study of their fishing operations. The authors dedicate this manuscript to the memory of Dr Nélio Barros, who left an important contribution to the knowledge about cetacean trophic interactions. Earthwatch Institute, Cetacean Society International and PROBIO (Projeto de Conservação e Utilização Sustentável da Diversidade Biológica Brasileira-Ministério do Meio 
Ambiente, with the support BIRD/GEF, and CNPq (20042005)) supported the studies of Guiana dolphins in the Cananéia estuary. Marcos Santos received grants from Fundação de Amparo à Pesquisa do Estado de São Paulo (FAPESP) to conduct his doctoral studies (process number 01/05128-8) and received grants from 'Programa Jovem Pesquisador-FAPESP' (process numbers 05/59439-5 and 05/54149-9). Xênia Moreira Lopes received grants from Fundação de Amparo à Pesquisa do Estado de São Paulo (FAPESP) (process number 08/55617-4).

\section{REFERENCES}

Abilhôa V. and Corrêa M.F.M. (1992-1993) Catálogo de otólitos de Carangidae (Osteichthyes-Perciformes) do litoral do Estado do Paraná, Brasil. Nerítica 7, 119-131.

Azevedo A.F., Lailson-Brito J., Dorneles P.R., Van Sluys M., Cunha H.A. and Fragoso A.B.L. (2008) Human-induced injuries to marine tucuxi (Sotalia guianensis) (Cetacea: Delphinidae) in Brazil. $J M B A 2$-Biodversity Records 1-5. DOI: 10.1017/S1755267208000262.

Barros N.B. and Clarke M.R. (2009) Diet. In Perrin W.F., Würsig B. and Thewissen J.G.M. (eds) Encyclopedia of marine mammals. San Diego, CA: Academic Press, pp. 311-316

Barros N.B. and Teixeira R.L. (1994) Incidental catch of marine tucuxi, Sotalia fluviatilis in Alagoas, northeastern Brazil. In Perrin W.F. Donavon G.P. and Barlow J. (eds) Gillnets and cetaceans. International Whaling Commission, Special Issue 12. Cambridge: Cambridge University Press, pp. 265-268.

Bassoi M. (2005) Feeding ecology of franciscana dolphin, Pontoporia blainvillei (Cetacea: Pontoporidae), and oceanographic processes on the Southern Brazilian coast. PhD thesis. Graduate School of the National Oceanography Centre, Southampton, England.

Bastos G.C. (1990) Morfologia de otólitos de algumas espécies de Perciformes (Teleostei) da costa Sudeste-Sul do Brasil. Master's dissertation. Universidade de São Paulo, São Paulo, Brazil.

Benoit-Bird K.J., Gilly W.F., Au W.W.L. and Mate B. (2008) Controlled and in situ target strengths of the jumbo squid Dosidicus gigas and identification of potential acoustic scattering sources. Journal of the Acoustical Society of America 123, 1318-1328.

Besnard W. (1950) Considerações gerais em torno da região lagunar de Cananéia-Iguape. Boletim do Instituto Paulista de Oceanografia 1 $9-26$.

Bittar V.T. (2007) Relações tróficas entre Trichiurus lepturus (Osteichthyes, Periformes) e Pontoporia blainvillei (Mammalia Cetácea) na costa norte do Rio de Janeiro. Master's dissertation. Universidade Estadual do Norte Fluminense Darcy Ribeiro, Rio de Janeiro, Brazil.

Borobia M. and Barros N.B. (1989) Notes on the diet of marine Sotalia fluviatilis. Marine Mammal Science 5, 395-399.

Budge S.M., Iverson S.J. and Koopman H.N. (2006) Studying trophic ecology in marine ecosystems using fatty acids: a primer on analysis and interpretation. Marine Mammal Science 22, 759-801.

Carvalho C.T. (1963) Sobre um boto comum no litoral do Brasil (Cetacea, Delphinidae). Revista Brasileira de Biologia 23, 263-276.

Clarke M.R. (1962) The identification of cephalopod 'beaks' and the relationship between beak size and total body weight. Bulletin of the British Museum (Natural History) 8, 419-480.

Clarke M.R. (1986) Cephalopods in the diet of odontocetes. In Bryden M.M. and Harrison R. (eds) Research on dolphins. Oxford: Clarendon Press, pp. 281-321.
Conceição J.M.S., Ribeiro M.R. and Silva M.C. (2005) Dinâmica populacional, biologia reprodutiva e o ictioplâncton de Cetengraulis edentulus Cuvier (Pisces, Clupeiformes, Engraulidae) na Enseada do Saco dos Limões, Florianópolis, Santa Catarina, Brasil. Revista Brasileira de Zoologia 22, 953-961.

Corrêa M.F.M. and Vianna M.S. (1992-1993) Catálogo de otólitos de Sciaenidae (Osteichthyes-Perciformes) do litoral do Estado do Paraná. Nerítica 7, 13-40.

Costa R.C., Fransozo A., Melo G.A.S. and Freire F.A.M. (2003) Chave ilustrada para identificação dos camarões dendrobranchiata do litoral morte do estado de São Paulo, Brasil. Bieta Neotrópica 3. Available at http://www.biotaneotropica.org.br/uznl/pt/abstract?iden tification-Key+BNo1503012003 (accessed 5 October 2011)

Cremer M. (2007) Ecologia e conservação de populações simpátricas de pequenos cetáceos em ambiente estuarino no sul do Brasil. $\mathrm{PhD}$ thesis. Universidade Federal do Paraná, Curitiba, Brazil.

Da Silva A.O.A. and Vianna M. (2009) A produção pesqueira do estado do Rio de Janeiro. In Vianna M. (ed.) Diagnóstico da cadeia produtiva da pesca marítima no estado do Rio de Janeiro: relatório de pesquisa. Rio de Janeiro: FAERJ: SEBRAE-RJ, pp. 47-6o.

Daura-Jorge F.G. (2007) A dinâmica predador-presa e o comportamento do boto-cinza, Sotalia guianensis (Cetacea, Delphinidae), na baía norte da Ilha de Santa Catarina, sul do Brasil. Master's dissertation. Universidade Federal do Paraná, Curitiba, Brazil.

Deagle B.E., Tollit D.J., Jarman N.J., Hindell M.A., Trites A. and Gales N.J. (2005) Molecular scatology as a tool to study diet: analysis of prey DNA in scats from captive Steller sea lions. Molecular Ecology 14, $1831-1842$.

Di Benedito A.P.M. and Ramos R.M.A. (2004) Biology of the marine tucuxi dolphin (Sotalia fluviatilis) in south-eastern Brazil. Journal of the Marine Biological Association of the United Kingdom 4, 1245-1250.

Di Beneditto A.P.M. and Siciliano S. (2007) Stomach contents of the marine tucuxi dolphin (Sotalia guianensis) from Rio de Janeiro, southeastern Brazil. Journal of Marine Biological Association of the United Kingdom 87, 253-254

Figueiredo J.C. and Menezes N.A. (2000) Manual de peixes marinhos do sudeste do Brasil. VI. Teleostei (5). São Paulo: Museu de Zoologia da Universidade de São Paulo.

Fitch J.E. and Brownell R.L. (1968) Fish otoliths in cetacean stomachs and their importance in interpreting feeding habits. Journal of the Fisheries Research Board of Canada 25, 1561-1574

Flores P.A.C. and Da Silva V.M.F. (2009) Tucuxi and Guiana dolphin, Sotalia fluviatilis and S. guianensis. In Perrin W.F., Würsig B. and Thewissen J.G.M. (eds) Encyclopedia of marine mammals. San Diego, CA: Academic Press, pp. 1188-1192.

Gurjão L.M., Neto M.A.A.F., Santos R.A. and Cascon P. (2003) Feeding habits of marine tucuxi, Sotalia fluviatilis, at Ceará state, northeastern Brazil. Latin American Journal of Aquatic Mammals 2, 117-122.

Haimovici M., Costa P.A.S., Santos R.A., Martins A.S. and Olavo G. (2007) Composição de espécies, distribuição e abundância de cefalópodes do talude da Região Central do Brasil. In Costa P.A.S., Olavo G. and Martins A.S. (eds) Biodiverdade da fauna marinha profunda na costa central brasileira (Séries Livros, $n$. 24). Rio de Janeiro: Museu Nacional, pp. 109-132.

Harvey J.T., Loughlin T.R., Perez T.R. and Oxman D.S. (2000) Relationship between fish size and otolith length for 63 species of fishes from the Eastern North Pacific Ocean. NOAA Technical Report NMFS150 - a technical report of the Fishery Bulletin. Seatle, USA

IUCN (2010) IUCN Red List of Threatened Species. Version 2010.3. Available at www.iucnredlist.org (accessed 30 September 2010). 
Iverson S.J., Field C.F., Don Bowen W. and Blanchard W. (2004) Quantitative fatty acid signature analysis: a new method of estimating predator diets. Ecological Monographs 74, 211-235.

Jobling M. and Breiby A. (1986) The use and abuse of fish otoliths in studies of feeding habits of marine piscivores. Sarsia 71, 265-274.

Lêmos P.H.B., Corrêa M.F.M. and Abilhôa V. (1992-1993) Catálogo de otólitos de Gerreidae (Osteichtyes-Perciformes) do litoral do Estado do Paraná, Brasil. Nerítica 7, 109-117.

Lêmos P.H.B., Corrêa M.F.M. and Pinheiro P.C. (1995a) Catálogo de otólitos de Engraulidae (Clupeiformes-Perciformes) do litoral do Estado do Paraná, Brasil. Brazilian Archives of Biology and Technology 38, 731-745.

Lêmos P.H.B., Corrêa M.F.M. and Pinheiro P.C. (1995b) Catálogo de otólitos de Clupeidae (Clupeiformes-Perciformes) do litoral do Estado do Paraná, Brasil. Brazilian Archives of Biology and Technology 38, 747-759.

Maciel N.A.L. (2001) Composição, abundância e distribuição espaço-temporal da ictiofauna do complexo estuarino-lagunar de IguapeCananéia-São Paulo-Brasil. $\mathrm{PhD}$ thesis. Universidade de São Paulo, São Paulo, Brazil.

Madsen P.T., Johnson M., Aguilar de Soto N., Zimmer W.M.X. and Tyack P.L. (2005) Biosonar performance of foraging beaked whales (Mesoplodon densirostris). Journal of Experimental Biology 208, 181194.

Magro M. (2005) Trichiurus lepturus Linnaeus, 1758. In Cergole M.C., Ávila-Da-Silva A.O. and Rossi-Wongtschowski C.L.D.B. (eds) Análise das principais pescarias comerciais da região Sudeste-Sul do Brasil: dinâmica populacional das espécies em explotaçao-Serie Revizee-Score sul. São Paulo, Brazil: Editora Ulhoa Cintra, pp. 162- 166.

Mendonça J.T. (1998) A pesca na região de Cananéia-SP, nos anos de 1995 e 1996. Master’s dissertation. Universidade de São Paulo, São Paulo, Brazil.

Mendonça J.T., Pires A.D., Calasans G.C., Xavier S.C. and Sena R.J. (2003) Produção pesqueira marinha do litoral sul do estado de São Paulo no período de 1967 a 1994. Série Relatórios Técnicos do Instituto de Pesca de São Paulo 13, 1-24.

Mendonça J.T., Pires A.D., Casalans G.C.C., Xavier S.C., Hoff E.A. and Sena R.J. (2004) Produção pesqueira marinha do litoral sul do Estado de São Paulo no período de 1995 a 2002-Projeto Pesca Sul Paulista. Série Relatórios Técnicos do Instituto de Pesca de São Paulo 18, 1-75.

Menezes N.A. and Figueiredo J.L. (1980) Manual de peixes marinhos do sudeste do Brasil. IV. Teleostei (3). São Paulo: Museu de Zoologia da Universidade de São Paulo.

Nery M.F., Espécie M.A. and Simão S.M. (2008) Marine tucuxi dolphin (Sotalia guianensis) injuries as a possible indicator of fisheries interaction in southeastern Brazil. Brazilian Journal of Oceanography 56, 313-316.

Newsome S.D., Clementz M.T. and Koch P.L. (2010) Using stable isotope biogeochemistry to study marine mammal ecology. Marine Mammal Science 26, 509-572.

Oliveira M.R. (2003) Ecologia alimentar de Sotalia guianensis e Pontoporia blainvillei (Cetacea, Delphinidae e Pontoporiidae) no litoral sul do estado de São Paulo e litoral do estado do Paraná. Master's dissertation. Universidade Federal do Paraná, Curitiba, Brazil.

Pauly D., Trites A.W., Capuli E. and Christensen V. (1998) Diet composition and trophic levels of marine mammals. ICES Journal of Marine Science 55, 467-481.

Perez J.A.A., Gasalla M.A., Aguiar D.C., Oliveira U.C., Marques C.A. and Tomás A.R.G. (2005) Doryteuthis plei (Blainville, 1823).
In Cergole M.C., Da Silva A.O.A. and Wongtschowski C.L.B.R. (eds) Análise das principais pescarias comerciais da região Sudeste-Sul do Brasil: dinâmica populacional das espécies em explotação. Serie Revizee-Score sul. São Paulo: Editora Ulhoa Cintra, pp. 62-68.

Rodrigues A.R. and Gasalla M.A. (2008) Spatial and temporal patterns in size and maturation of Doryteuthis plei and Doryteuthis sanpaulensis (Cephalopoda: Loliginidae) in south-eastern Brazilian waters, between $23^{\circ} \mathrm{S}$ and $27^{\circ} \mathrm{S}$. Scientia Marina $72,631-643$.

Roper C.F.E., Sweeney M.J. and Nauen C.E. (1984) FAO Species Catalogue. Volume 3. Cephalopods of the World. An annotated and illustrated catalogue of species of interest to fisheries. FAO Fisheries Synopsis 3, 1-277.

Rosas F.C.W., Marigo J., Laeta M. and Rossi-Santos M.R. (2010) Natural history of dolphins of the genus Sotalia. Latin American Journal of Aquatic Mammals 8, 57-68.

Santos M.C. de O., Rosso S., Santos R.A. dos, Lucato S.H.B. and Bassoi M. (2002) Insights on small cetacean feeding habits in southeastern Brazil. Aquatic Mammals 28, 38-45.

Santos M.C. de O. and Rosso R. (2007) Ecological aspects of marine tucuxi dolphins (Sotalia guianensis) based on group size and composition in the Cananéia estuary, southeastern Brazil. Latin American Journal of Aquatic Mammals 6, 71-82.

Santos R.A. (1999) Cefalópodes nas relações tróficas do sul do Brasil. $\mathrm{PhD}$ thesis. Fundação Universidade do Rio Grande, Rio Grande, Brazil.

Schaeffer-Novelli Y., Mesquita H. de S. and Cintrón-Molero G. (1990) The Cananéia lagoon estuarine system, São Paulo, Brazil. Estuaries 13, $193-203$.

Schmiegelow J.M.M. (1990) Estudo sobre cetáceos odontocetes encontrados em praias da região entre Iguape (SP) e Baía de Paranaguá (PR) $\left(24^{\circ} 42^{\prime} S-25^{\circ} 28^{\prime} S\right)$ com especial referência a Sotalia fluviatilis (Gervais, 1853) (Delphinidae). Master's dissertation. Universidade de São Paulo, São Paulo, Brazil.

Siciliano S. (1994) Review of small cetaceans and fishery interactions in coastal waters of Brazil. Reports of the International Whaling Commission Special Issue 15, 241-250.

Souza U.P.S. (2004) Estrutura da comunidade dos organismos demersais no litoral norte do estado de São Paulo. Master's dissertation. Universidade Estadual Júlio de Mesquita Filho-Campus Botucatu, Botucatu, Brazil.

Symondson W.O.C. (2002) Molecular identification of prey in predator diets. Molecular Ecology 11, 627-641.

and

Zanelatto R.C. (2001) Dieta do boto-cinza, Sotalia fluviatilis (Cetacea, Delphinidae), no complexo estuarino da Baia de Paranaguá e sua relação com a ictiofauna estuarina. Master's dissertation. Universidade Federal do Paraná, Curitiba, Brazil.

\section{Correspondence should be addressed to:}

X.M. Lopes

Projeto Atlantis, Laboratório de Biologia da Conservação de Cetáceos

Departamento de Zoologia

Instituto de Biociências da Universidade Estadual Paulista 'Júlio de Mesquita Filho' (UNESP)

Campus Rio Claro, Avenida 24-A, 1515, Bela Vista, Rio Claro, SP, Brazil email: xeniamlopes@gmail.com 